\title{
Epiphytic dinoflagellates associated with ciguatera in the northwestern coast of $\mathrm{Cuba}$
}

\author{
Gilma Delgado ${ }^{1}$, Carlos H. Lechuga-Devéze ${ }^{2 *}$, Genoveva Popowski ${ }^{3}$, Luis Troccoli ${ }^{4} \&$ \\ Cesar A. Salinas ${ }^{2}$ \\ 1 Centro de Investigaciones Pesqueras. 5a Avenida y Calle 246, Barlovento, Santa Fe, Playa. P.O. Box 19100. Ciudad \\ de La Habana, Cuba; gdelgado@cip.telemar.cu \\ 2 Centro de Investigaciones Biológicas del Noroeste. Mar Bermejo 195, Col. Playa Palo de Santa Rita, La Paz, Baja \\ California Sur 23090, México; clechuga@cibnor.mx ; csalinas04@cibnor.mx \\ 3 Centro Nacional de Termalismo. Avenida 243 \#19815. Reparto Fontanar. Boyeros. Apdo. Postal 19500. Ciudad de la \\ Habana, Cuba; popowski_17@yahoo.es \\ 4 Universidad de Oriente. Escuela de Ciencias Aplicadas del Mar Calle Marina. Boca de Río. Apdo. Postal 6304. Isla \\ de Margarita, Venezuela; ltroccoli@hotmail.com \\ * Corresponding author: clechuga@cibnor.mx
}

Received 04-IV-2005. Corrected 01-VII-2005. Accepted 13-X-2005.

\begin{abstract}
The spatial and temporal abundance of epiphytic dinoflagellates associated with ciguatera was studied over two annual cycles (March 1999 to March 2000 and March 2001 to March 2002) in the northwestern coast of Cuba. From 14 species of macroalgae (Phaeophyta, Chlorophyta, and Rhodophyta), 1340 samples were obtained identifying seven species as potentially noxious; five of them are new reports for Cuba's phytobenthos: Prorocentrum belizeanum Faust, P. concavum Fukuyo, P. mexicanum Tafall, Coolia monotis Meunier, and Ostreopsis lenticularis Fukuyo. ANOVA/MANOVA analysis showed significant spatial differences: lower cell abundance near the shoreline adjacent to a river inlet and higher cell abundance in the deepest area. Prorocentrum lima (Ehrenberg) Dodge 1975 was found mainly on Phaeophyta followed by Chlorophyta and Rhodophyta. Gambierdiscus toxicus was found mainly on Phaeophyta followed by Rhodophyta and Chlorophyta. All the species reported in the study area were mainly on Padina spp. (Phaeophyta). Acanthophora spicifera (Rhodophyta) did not host dinoflagellate species. Environmental conditions in summer (higher temperature, more nutrients, greater water transparency, and low wind intensity) are suitable for macroalgae development, which serves as a substrate for potentially harmful dinoflagellates, and possibly the main vector for spreading ciguatera along the coast of Cuba. Rev. Biol. Trop. 54(2): 299-310. Epub 2006 Jun 01.
\end{abstract}

Key words: benthic dinoflagellates, abundance, Cuba, ciguatera.

The abundance and distribution of toxic dinoflagellates in world marine ecosystems has increased considerably (Hallegraff 1995). Some of these dinoflagellates are benthic species and commonly associated with macroalgae, sediments, corals reefs, and seagrass (Faust 1991). Epiphytic toxic dinoflagellates are responsible for diarrhea, ciguatera, and PSP poisoning (Faust 1996). The genera Gambierdiscus (Adachi and Fukuyo 1979), Ostreopsis, Prorocentrum (Fukuyo 1981), and
Coolia (Besada et al. 1982), found in epiphytic association with green, brown, and red macroalgae, are the main vectors of the toxins involved in these diseases.

Toxic dinoflagellates are mainly found in tropical and subtropical regions of the Pacific Ocean, Indian Ocean, and the Caribbean (Yasumoto et al. 1980, Bagnis et al. 1988, Bomber et al. 1985, Carlson and Tindall 1985, Faust 1991, 1996, Barraza et al. 2004, BravoSierra 2004, Gárate-Lizárraga et al. 2004, 
García-Hansen et al. 2004, Hernández-Becerril and Almazán Becerril 2004, La BarberaSánchez et al. 2004, Sierra-Beltrán et al. 2004, Tosteson 2004, Vargas-Montero and Freer 2004). Variability in noxious epiphytic dinoflagellates has been attributed to natural and anthropogenic changes affecting macroalgal assemblages, such as: temperature, turbulence, nutrients, changes in substrates, fresh water sources, waves, inputs of limestone on dead coral and seagrass, as well as effects of hurricanes and strong cold fronts (Taylor 1985, Diogène 1992, Grzebyk 1994).

In the inlet of the Jaimanitas River near Havana, the sediment is muddy at the river outlet, muddy to sandy further out, and sandy farther offshore. The macrophytic assemblages are composed of three functional-form groups: filamentous, foliaceous, and arborescent (Littler and Littler 1980). Each group is dependent on sediment type and belongs to the following genera: Ceramium, Bryothammnion, Hypnea, Acanthophora, Gracillaria, Gelidium, Ectocarpus, Sphacelaria, Dictyota, Padina, Ulva, Cladophora, Codium, and Chaetomorpha, all belonging to the Phaeophyta, Chlorophyta, or Rhodophyta group.

Even though ciguatera is one of the main causes of food poisoning from fish in northwestern Cuba, the first studies were performed in the 1990s (Valdés et al. 1992, Delgado et al. 2000, Popowski et al. 2001), which concluded that these organisms were more abundant on brown macroalgae during the summer.

This study describes abundance and spatial and temporal distribution of potentially harmful epiphytic dinoflagellates and their association with macroalgae substrate, according to factors influencing environmental variability.

\section{MATERIAL AND METHODS}

Sampling during two annual cycles (March to March of 1999-2000 and 20012002) was performed in two transects (5 sampling stations per transect) perpendicular to the shore in the sub tidal zone $(0.50-4 \mathrm{~m}$ depth) of Jaimanitas Inlet $\left(23^{\circ} 5^{\prime} 37.29^{\prime \prime} \mathrm{N}\right.$, $82^{\circ} 29^{\prime} 20.86$ " W), located $6 \mathrm{~km}$ northwest of Havana, Cuba. The Jaimanitas River is surrounded by urban development. Salinity varies from 10 to 38 psu according to freshwater fluxes during rainy season.

Macroalgae samples were collected monthly by snorkelling, following the procedure proposed by Quod et al. (1995). Macroalgae were collected (20 to $100 \mathrm{~g} / \mathrm{m}^{2}$ ) and placed in plastic bags.

At the laboratory, the algal samples were vigorously shaken to remove epiphytic dinoflagellates. The suspension was passed through three successive $150,100,75$, and $20-\mu \mathrm{m}$ mesh sieves. The last fraction retained $(20 \mu \mathrm{m})$ was preserved in $25 \mathrm{ml}$ seawater containing $1 \mathrm{ml}$ lugol acid. During the two annual cycles, 1340 samples were obtained. Macroalgae were dried on filter paper for $72 \mathrm{~h}$ before weighing (Sauter D-7470, EB Ingen, $0.01 \mathrm{mg}$ precision).

Cell concentrations were calculated for all samples by counting $1 \mathrm{ml}$ preserved sample on a Sedgwick-Rafter chamber with a light microscope (Olympus). Cells were expressed in cells/g algae (wet weight). Dinoflagellates were identified using Adachi and Fukuyo (1979), Fukuyo (1981), Faust (1991, 1996), and Tomas (1997).

Water samples near the bottom were collected to determine $\mathrm{NH}_{4}, \mathrm{NO}_{3}$, and $\mathrm{NO}_{2}$ concentrations following the procedures reported by IOC (1993). Total inorganic nitrogen (TIN) was estimated adding known amounts of $\mathrm{NH}_{4}$, $\mathrm{NO}_{3}$ and $\mathrm{NO}_{2} \cdot \mathrm{PO}_{4}$ and total (TP) concentrations were estimated as described in IOC/ UNESCO (1983). Salinity and temperature were measured with a bucket thermometer and refractometer (ATAGO).

To determine significant differences between dinoflagellates abundance and chemical and physical variables, an ANOVA/ MANOVA analysis was used, followed by a LSD analysis if significant differences were found. The relationship between the density of G. toxicus and P. lima and environmental variables were tested by Principal Component Analysis (PCA). All statistical analysis was 
performed with Statistica $^{\mathrm{TM}}$ v. 4.5 software (StatSoft, Inc., Tulsa, OK).

\section{RESULTS}

\section{Hydrological characteristics}

Annual nutrient concentrations ( $\mu \mathrm{mol} / \mathrm{l})$, temperature $\left({ }^{\circ} \mathrm{C}\right)$, salinity (psu), and mean wind speed $(\mathrm{m} / \mathrm{s})$ maximum and minimum values are shown in Table 1 . The $\mathrm{NH}_{4}$ showed the higher concentration $(>65 \%$ TIN) during the two annual cycles. Maximum and minimum temperatures were typical for the seasons $\left(32.9^{\circ} \mathrm{C}\right.$ during the summer and $25^{\circ} \mathrm{C}$ during the winter). Salinity values oscillated from brackish (10.3 psu) to seawater (38.3 psu) values and wind speeds from 0.5 to $10.5 \mathrm{~m} / \mathrm{s}$. During May-October, the highest concentrations of $\mathrm{NO}_{3}, \mathrm{NH}_{4}, \mathrm{PO}_{4}, \mathrm{TIN}$, and TP occurred. The lowest salinity occurred during the 1999-2000 cycle (Table 2).

\section{Composition of epiphytic harmful dinoflagellates}

Seven species in four genera of harmful epiphytic dinoflagellates were identified; of these, five are first reports for Cuban waters. Four species of Prorocentrum were the most abundant (Table 3).

\section{Abundance and distribution of harmful dinoflagellates}

Harmful dinoflagellates were found at all the stations during both annual cycles. There was an insignificant difference in cell numbers between transects (ANOVA/MANOVA $p<0.05)$. Higher abundance occurred at the deeper sampling stations ( 5 and 6 ) with mean values of 1150 and 1120 cell g$^{-1}$ for the first

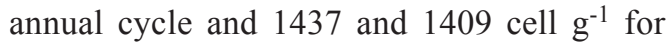
the second one. Low abundance of harmful dinoflagellates was found at Station 1, near the mouth of the river, during both

TABLE 1

Annual mean (min-max and SD) values of nutrient concentration ( $\mu \mathrm{mol}$ ), temperature $\left({ }^{\circ} \mathrm{C}\right)$, salinity (psu), and wind speed $(\mathrm{m} / \mathrm{s})$ during two annual cycles

Parameters

$\begin{array}{lcccccccc} & \text { Max } & \text { Min } & \text { Mean } & \text { S.D } & \text { Max } & \text { Min } & \text { Mean } & \text { S.D. } \\ \text { Temperature }\left({ }^{\circ} \mathrm{C}\right) & 32.5 & 26.1 & 28.57 & 1.91 & 32.4 & 25 & 29.01 & 2.07 \\ \text { Salinity }(\mathrm{psu}) & 38.3 & 10.3 & 31.09 & 7.95 & 35.8 & 30 & 33.07 & 1.84 \\ \text { Wind }(\mathrm{m} / \mathrm{s}) & 10.5 & 0 & 3.9 & 3.66 & 7.5 & 0.5 & 2.51 & 2.24 \\ \mathrm{NO}_{3}(\mu \mathrm{mol} / \mathrm{l}) & 12.15 & 0.2 & 4.57 & 3.24 & 8.93 & 1.09 & 5.05 & 2.3 \\ \mathrm{NO}_{2}(\mu \mathrm{mol} / \mathrm{l}) & 0.15 & 0 & 0.03 & 0.10 & 0.15 & 0 & 0.004 & 0.015 \\ \mathrm{NH}_{4}(\mu \mathrm{mol} / \mathrm{l}) & 39.88 & 0.8 & 10.68 & 9.16 & 18.83 & 3.07 & 9.99 & 4.33 \\ \mathrm{TIN}_{(\mu \mathrm{mol} / \mathrm{l})} & 52.84 & 1.4 & 15.24 & 12.15 & 27.76 & 4.16 & 15.14 & 6.54 \\ \mathrm{PO}_{4}(\mu \mathrm{mol} / \mathrm{l}) & 4.28 & 0.005 & 1.09 & 1.16 & 1.83 & 0.007 & 0.88 & 0.56 \\ \mathrm{TP}_{(\mu \mathrm{mol} / \mathrm{l})} & 7.87 & 0.07 & 1.97 & 1.84 & 2.38 & 0.003 & 1.42 & 0.57\end{array}$


TABLE 2

Monthly mean values of physico-chemical variability in two annual cycles

Period 1999-2000

\begin{tabular}{|c|c|c|c|c|c|c|c|c|c|c|c|c|c|}
\hline Parameters & M & A & M & $\mathrm{J}$ & $\mathrm{J}$ & A & $\mathrm{S}$ & $\mathrm{O}$ & $\mathrm{N}$ & $\mathrm{D}$ & $\mathrm{E}$ & $\mathrm{F}$ & M \\
\hline Temperature $\left({ }^{\circ} \mathrm{C}\right)$ & 26.42 & 27.4 & 28.48 & 30.2 & 30.85 & 31.44 & 31.40 & 30.18 & 26.88 & 27.39 & 27.05 & 26.42 & 27.42 \\
\hline Salinity (psu) & 34.28 & 35.34 & 0.5 & 31.75 & 31.34 & 19.52 & 11.61 & 33.3 & 36.03 & 35.17 & 37.83 & 37.97 & 37.81 \\
\hline Wind $(\mathrm{m} / \mathrm{s})$ & 0.35 & 5.00 & 22.27 & 0.5 & 1.5 & 1.5 & 0.5 & 1.5 & 10.5 & 8.5 & 0.5 & 9.42 & 1.2 \\
\hline $\mathrm{NO}_{3}(\mu \mathrm{mol} / 1)$ & 3.53 & 2.24 & 4.23 & 5.39 & 3.83 & 8.98 & 11.25 & 4.26 & 3.81 & 3.36 & 2.66 & 2.54 & 3.40 \\
\hline $\mathrm{NO}_{2}(\mu \mathrm{mol} / 1)$ & 0.02 & 0.007 & 0.02 & 0.01 & 0.007 & 0.01 & 0.23 & 0.007 & 0.02 & 0.001 & 0.000 & 0.000 & 0.02 \\
\hline $\mathrm{NH}_{4}(\mu \mathrm{mol} / 1)$ & 7.29 & 5.61 & 12.79 & 13.42 & 6.64 & 16.06 & 37.95 & 8.07 & 6.91 & 6.63 & 5.37 & 5.21 & 6.88 \\
\hline $\mathrm{TIN}(\mu \mathrm{mol} / \mathrm{l})$ & 10.84 & 7.86 & 17.06 & 18.91 & 10.48 & 24.69 & 49.43 & 12.34 & 10.74 & 9.68 & 8.03 & 7.75 & 10.31 \\
\hline $\mathrm{PO}_{4}(\mu \mathrm{mol} / 1)$ & 0.45 & 0.22 & 1.32 & 1.45 & 0.96 & 2.45 & 4.13 & 0.96 & 0.79 & 0.46 & 0.21 & 0.22 & 0.56 \\
\hline $\mathrm{TP}(\mu \mathrm{mol} / \mathrm{l})$ & 1.1 & 0.48 & 1.80 & 2.04 & 1.53 & 4.34 & 7.07 & 1.53 & 1.47 & 1.19 & 1.02 & 0.88 & 1.15 \\
\hline & \multicolumn{13}{|c|}{ Period 2001-2002 } \\
\hline Parameters & M & A & M & $\mathrm{J}$ & $\mathrm{J}$ & A & $\mathrm{S}$ & $\mathrm{O}$ & $\mathrm{N}$ & $\mathrm{D}$ & $\mathrm{E}$ & $\mathrm{F}$ & M \\
\hline Temperature $\left({ }^{\circ} \mathrm{C}\right)$ & 27.52 & 27.35 & 29.41 & 30.35 & 30.85 & 31.68 & 31.5 & 30.33 & 30.5 & 28.59 & 26.52 & 25.26 & 27.44 \\
\hline Salinity (psu) & 34.83 & 34.62 & 31.75 & 32.31 & 31.31 & 31.56 & 30.81 & 31.24 & 33.17 & 34.53 & 34.85 & 34.41 & 34.63 \\
\hline Wind $(\mathrm{m} / \mathrm{s})$ & 0.35 & 5 & 0.5 & 0.5 & 0.85 & 1.5 & 0.5 & 2.85 & 1.35 & 2.5 & 5.44 & 7.5 & 3.5 \\
\hline $\mathrm{NO}_{3}(\mu \mathrm{mol} / \mathrm{l})$ & 3.39 & 2.7 & 5.47 & 5.40 & 7.07 & 6.80 & 7.87 & 6.68 & 6.96 & 4.15 & 3.48 & 3.58 & 2.12 \\
\hline $\mathrm{NO}_{2}(\mu \mathrm{mol} / \mathrm{l})$ & 0.01 & 0.009 & 0.003 & 0.01 & 0.002 & 0.007 & 0.002 & 0.001 & 0.003 & 0.003 & 0.004 & 0.000 & 0.000 \\
\hline $\mathrm{NH}_{4}(\mu \mathrm{mol} / 1)$ & 7.02 & 5.50 & 12.18 & 13.04 & 13.55 & 12.23 & 17.2 & 11.76 & 11.68 & 8.85 & 6.10 & 6.05 & 4.69 \\
\hline $\mathrm{TIN}(\mu \mathrm{mol} / \mathrm{l})$ & 10.43 & 8.22 & 17.66 & 18.53 & 20.62 & 18.96 & 25.07 & 18.45 & 18.65 & 13.00 & 9.58 & 9.64 & 6.81 \\
\hline $\mathrm{PO}_{4}(\mu \mathrm{mol} / \mathrm{l})$ & 0.28 & 0.21 & 1.22 & 1.34 & 1.33 & 1.27 & 1.55 & 1.23 & 1.49 & 0.60 & 0.30 & 0.33 & 0.24 \\
\hline $\mathrm{TP}(\mu \mathrm{mol} / \mathrm{l})$ & 1.00 & 0.39 & 1.64 & 2.07 & 1.84 & 1.75 & 1.97 & 1.83 & 1.82 & 1.23 & 1.01 & 1.07 & 0.91 \\
\hline
\end{tabular}

cycles, with mean concentrations of 175 and

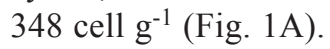

$P$. lima was the dominant species $(<50 \%)$ at all sampling stations followed by $G$. toxicus ( 8 to $33 \%$ ). The remaining species were lower than $8 \%$ (Figs. 1B and 1C).

The average abundance in the two annual cycles during March-July was the highest in June (1012 and 1089 cell g $^{-1}$ ), respectively. The distribution pattern changes between August and November, reaching the lowest mean concentration (21 cell g-1) in February (Fig. 2A). In 1999-2000, we observed a very abrupt decline in the amount of cells during August and September. During this month, no noxious dinoflagellate species were found. A second peak of abundance ( 609 cells g $\left.^{-1}\right)$ occurred during October (Fig. 2A).

P. lima was the most abundant species in both cycles, except during April and May 
TABLE 3

Benthic harmful dinoflagellates identified in the study area, and relative abundance in two cycles

Species

Gambierdiscus toxicus Adachi \& Fukuyo

Prorocentrum lima (Ehrenberg) Dodge

P. belizeanum Faust*

P. mexicanum Osorio-Tafall*

P. concavum Fukuyo*

Coolia monotis Meunier*

Ostreopsis lenticularis Fukuyo*
Periods

1999-2000 2001-2002

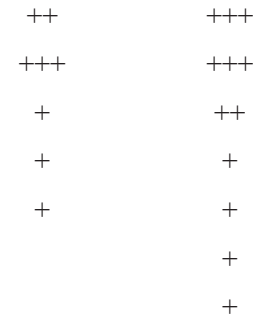

$+<10^{3}$ cell.g $\mathrm{g}^{-1} ;++10^{3}>10^{4}$ cell.g $\mathrm{g}^{-1} ;+++10^{4}>10^{5}$ cell. $\mathrm{g}^{-1} . *$ New report for Cuba.

1999, when G. toxicus represented 66.75 and $56.62 \%$, respectively, and in May 2001, when this species represented $51 \%$ of the total dinoflagellates; the others species were present in low concentrations (Figs. 2B, 2C).

Harmful dinoflagellates occurred in greater numbers on Phaeophyta and Chlorophyta macroalgae during both study periods: 19992000 (39 to 57\%) and 2001-2002 (36 to $62 \%)$. Abundance of $P$. lima was most important on Padina sp and Dictyota dicotoma (Phaeophyta, 82\%), than on Ulva lactuca and Chaetomorpha spp. (Chlorophyta, 17\%, Fig. 3A.). G. toxicus was mainly found covering D. dicotoma and Padina sp. (Phaeophyta, 78\%), Hypnea cervicornis (Rhodophyta, 17\%), and Chaetomorpha and Ulva lactuca (Chlorophyta, 5\%, Fig. 3B). Padina sp. was the sole macroalgae where the seven species of noxious dinoflagellates were found.

ANOVA/MANOVA was applied to the abundance data for $P$. lima and $G$. toxicus between transects, sampling stations, and months, showing no significant differences $(p>0.05)$ among transects. However, for $P$. lima, there are significant differences $(p>0.05)$ between stations and months. LSD analysis showed that Sampling Station No. 5 differed of the other ones during May and October in the first study period and in June during the second cycle. G. toxicus showed significant differences $(p>0.05)$ in the months of May and June (1999-2000) and May (2001-2002).

For 1999-2000, significant and positive correlations were observed in Component I of the variables (nutrients and temperature) and negative correlations with salinity; this suggests an effect related to the contribution of fresh water. In Component II, both dinoflagellates species have similar responses to environmental variables. Therefore, we suggest that the conditions facilitate development of both species (Fig. 4A). In 2001-2002, abundance and distribution was similar to the previous period. Nutrients are positively and significantly associated with Component I (except for nitrite) and negatively associated with salinity. The same was observed for the Component II, where the two dinoflagellate species are significantly associated (Fig. 4B).

\section{DISCUSSION}

Most Cuban industries and population settlements are located near rivers using it for disposal of wastewater. The rivers introduce elevated amounts of nitrogen and phosphorus 

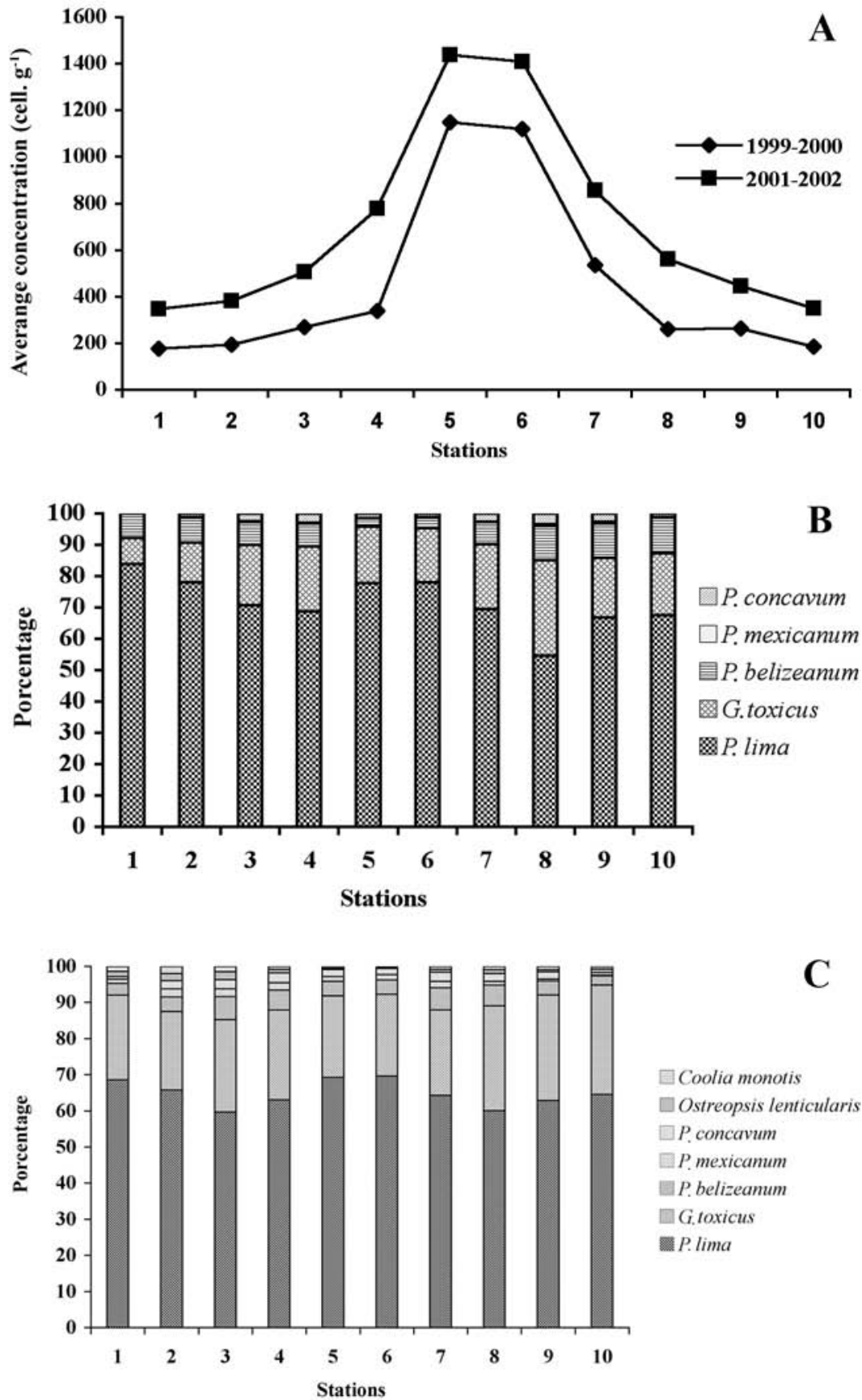

Fig. 1. A. Distribution and average abundance of harmful dinoflagellates found at sampling stations (March 1999-2000 to March 2001-2002). B. Percentage of harmful dinoflagellates at each station by species from March 1999 to March 2000. C. Percentage of harmful dinoflagellates in each station by species from March 2001 to March 2002. 

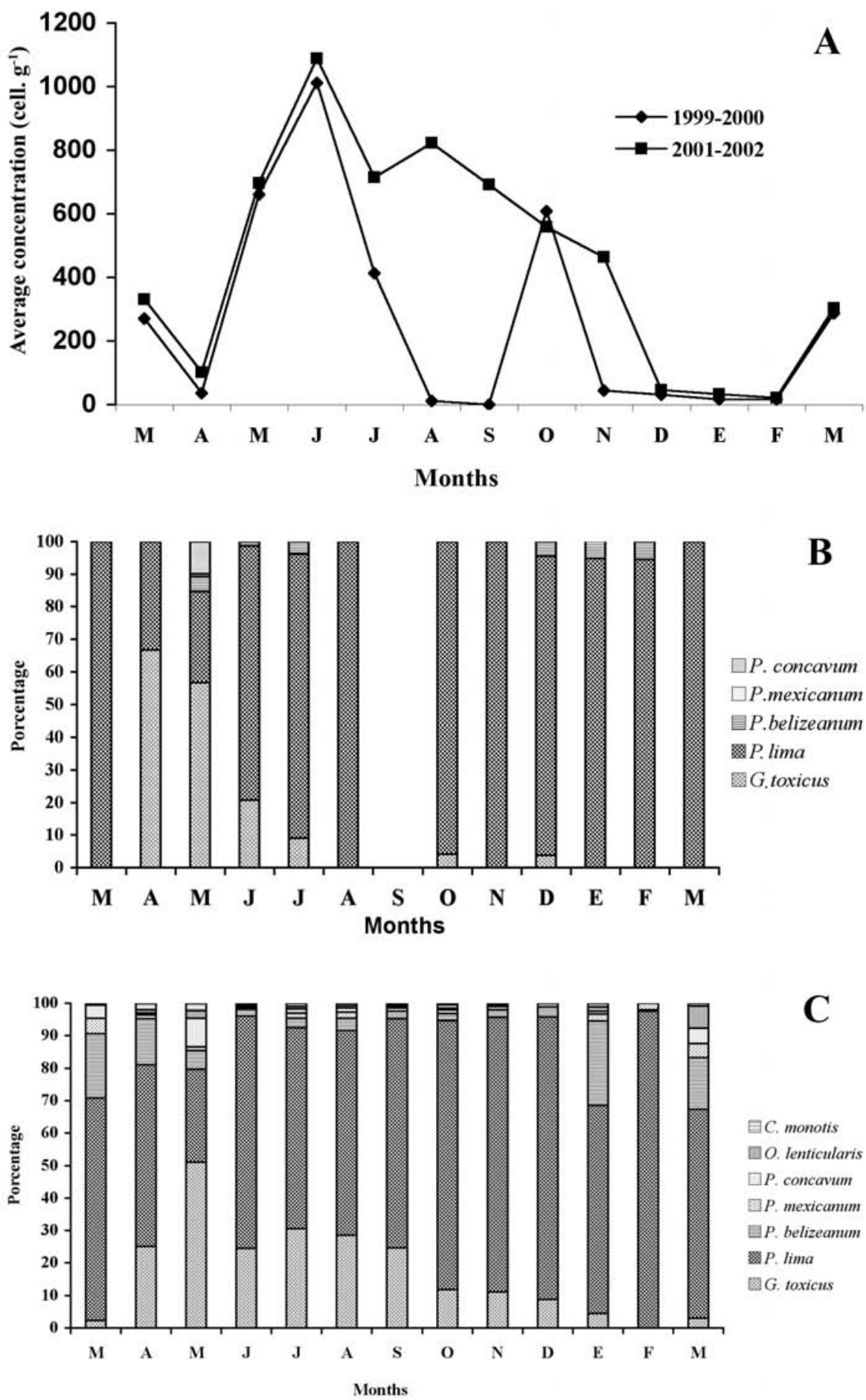

Fig. 2. A. Monthly average abundance of harmful dinoflagellates from March 1999-2000 to March 2001-2002. B. Percentage of harmful dinoflagellates species by month from March 1999 to March 2000. C. Percentage of harmful dinoflagellates species by month from March 2001 to March 2002. 

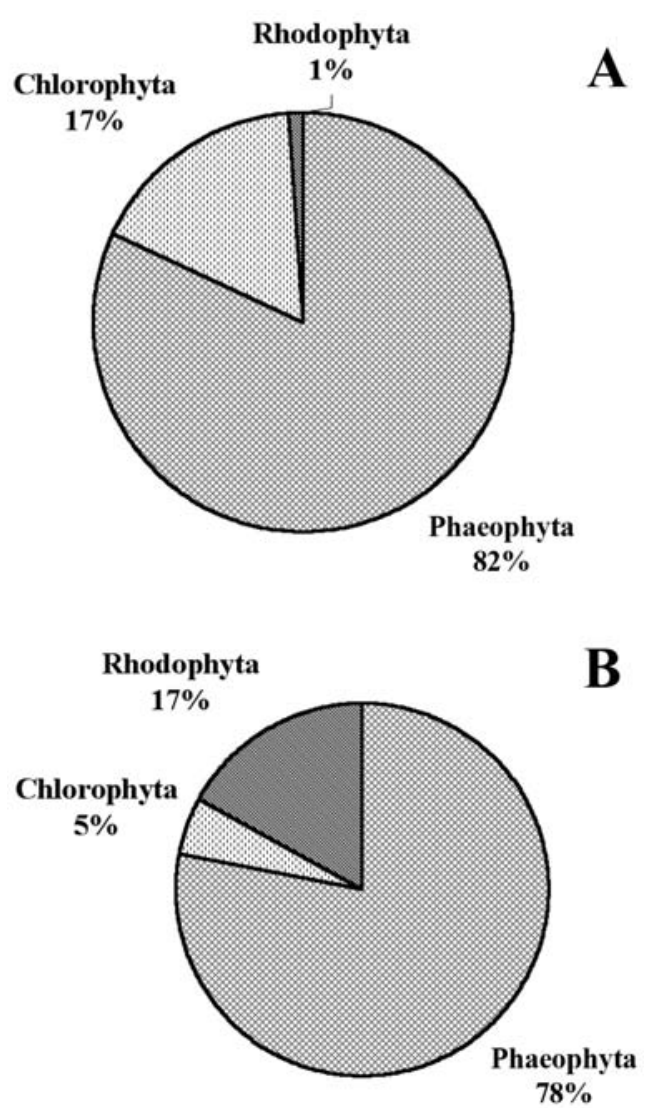

Fig. 3. A. Percentage of $P$. lima in each group of macroalgae (Phaeophyta, Chloropyta, and Rhodophyta). B. Percentage of G. toxicus in each group of macroalgae (Phaeophyta, Chloropyta, and Rhodophyta).

along the coast, creating a deleterious effect on bays and coastal lagoons (González 1990). The large quantities of nitrates and nitrates found in the Jaimanitas River has also been demonstrated by Montalvo et al. (2001), as was the case for large quantities of phosphorus, considered representative of eutrophic areas (D’Avanzo 1994). Similar examples of nitrogen compounds arise from human activity in many Caribbean coast (Schaffalke 1999).

All the dinoflagellates species found in this study have been reported by Morton and Faust (1997) as potentially toxic along the Belize coast, and probably associated with outbreaks of ciguatera. Abundance of these species is within the range reported by Gillespie et al. (1985), Bagnis et al. (1988), McCaffrey

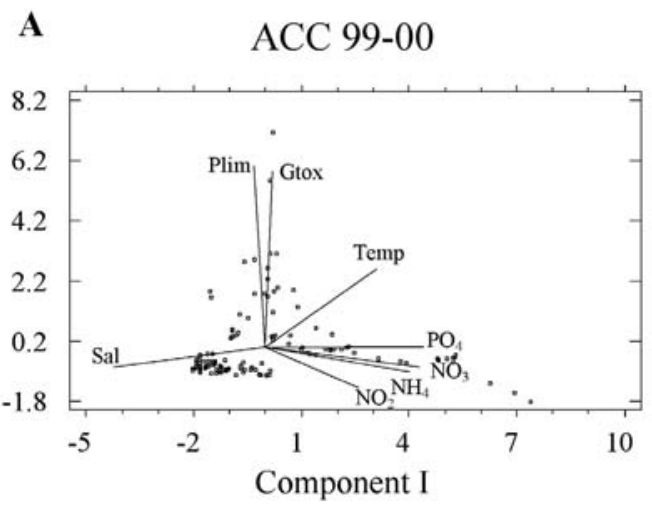

B $\quad$ ACC 01-02

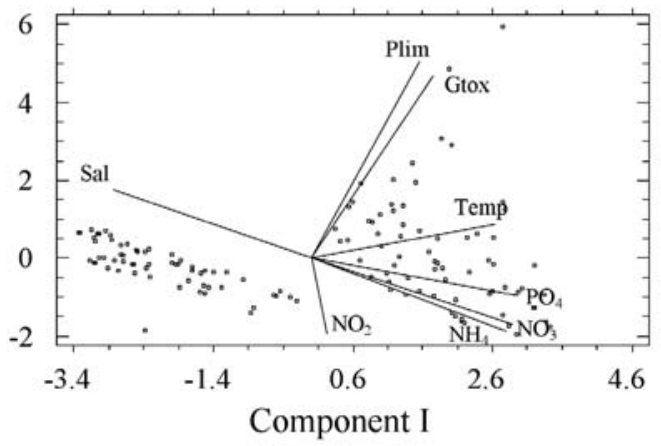

Fig. 4. A. Relationship between P. lima and G. toxicus abundance and physical-chemical variables obtained from Principal Component Analysis of data during 1999-2000. B. Relationship between P. lima and G. toxicus abundance and physical-chemical variables obtained from Principal Component Analysis of data during 2001-2002.

et al. (1990). For the Pacific coast, Taylor and Gustavson (1986), Carlson and Tindall (1985) have reported similar results; Morton and Faust (1997) reported on the Caribbean and Florida keys. Their abundance is not higher than those reported for the Gambier Islands in the southeast Pacific Ocean (Yasumoto et al. 1980, Bomber et al. 1989).

High harmful dinoflagellates concentrations in May and October are related to physicochemical conditions in this area, influenced by large quantities of nutrients introduced by the Jaimanitas River during the summer rainy season. Higher water temperatures, nutrient concentrations, and increased water transparency 
are factors promoting the growth of macroalgae and epiphytic dinoflagellates. In the western Caribbean, Taylor and Gustavson (1986) found wide distribution of G. toxicus except at those locations receiving significant freshwater, similar to what was found in this study, since $G$. toxicus was more abundant farther offshore. Lower abundance seems to be related to heavy rainfall $(338 \mathrm{~mm})$ in August and September 1999 from decreasing salinity and water transparency. The heavy rain disturbed the substrate; in the area near of the mouth of the Jaimanitas River, only filamentous algae (Chaetomorpha) remained, while at greater distance offshore, there were some patches of Padina sp. All macroalgae showed that sediment deposition probably limited the growth of dinoflagellates. G. toxicus cannot produce cysts under growth-limiting conditions, but $P$. lima does; hence, once the disturbance passed, $P$. lima is able to colonize the macroalgae, as occurred in October, when this species representing $96 \%$ of the dinoflagellates counted.

In the absence of heavy rain, G. toxicus was abundant under weak wind conditions, calm seas, and increased water transparency (Popowski et al. 2001) in the vicinity of Havana (May to August). Turket et al. (1998) found low abundance of $G$. toxicus in the Reunion Islands when strong winds produced heavy waves. Low concentrations seem to be characteristic when cold fronts reach the northern coast of Cuba from November to February. Bordeaux and Durant-Clement (1991) suggest that cold fronts, increase of water turbidity, and currents limit the growth of this species, as also shown in this study.

In our study, G. toxicus was more abundant in May during the first study year and May-June during the second year, both occurring with the beginning of the rainy season and the end of the winter season. Under the conditions in May, the increase of epiphytic dinoflagellates probably depends on several environmental factors acting at the same time (Carlson and Tindall 1985).

The higher abundance of potentially noxious dinoflagellates occur during the summer
(Valdés et al. 1992), when, according to Cuban Public Health Ministry statistics, most cases of ciguatera poisoning occur, most of them in this region. Carrera and Castro (2002) also determined that, even though the disease is present throughout the year, its incidence increases from March through October.

Prorocentrum is one of the most important genera among dinoflagellates because many species are toxic or potentially toxic and are widespread. In this area, $P$. lima predominates in abundance and spatial-temporal distribution of toxic dinoflagellates and is perennially present. Bomber et al. (1985) reported this species during the entire year in the Florida Keys, being more abundant from November to May. Heil et al. (1998) reported that this species is the most abundant along Australian shores and is associated with ciguatera.

Yasumoto et al. (1980) and Grzebyk et al. (1994) hold the view that $G$. toxicus develops best on Rhodophyta; however in this area, $G$. toxicus and P. lima were found on three macroalgal groups, and were most abundant on Phaeophyta. Heil et al. (1998) reports that, in Australian waters, $P$. lima grows on brown algae. In an artificial bay in northwestern Cuba, Delgado et al. (2000) and Popowski et al. (2001) report the preference of this dinoflagellate for brown algae. Saint-Martin et al. (1988) suggest that the preference of $G$. toxicus for macroalgae is independent of macroalgal phylum.

\section{ACKNOWLEDGMENTS}

This work was partially financed by the National Council of Science and Technology (CONACYT doctoral grant 182855) of México awarded to G. Delgado. We thank divers Erick Escobar, Ramón Barrera, and Carlos Reyes who collected samples, the staff of the marine shrimp laboratory of the Fishery Research Centre for their help in primary processing of samples, Norberto Capetillo for his suggestions for data analysis, and Yania Yáñez for the preliminary English translation. 


\section{RESUMEN}

Se estudió la abundancia espacial y temporal de dinoflagelados epífitos asociados a la ciguatera durante dos ciclos anuales (marzo 1999 a marzo 2000, y marzo 2001 a marzo 2002) en la costa del noroeste de Cuba. Recolectamos 14 especies de macroalgas (Phaeophyta, Chlorophyta y Rhodophyta) y obtuvimos 1340 muestras. Identificamos siete especies de dinoflagelados potencialmente nocivas, cinco de ellas nuevos registros para el fitobentos cubano: Prorocentrum belizeanum Faust, P. concavum Fukuyo, $P$. mexicanum Tafall, Coolia monotis Meunier, y Ostreopsis lenticulares Fukuyo. El análisis de ANOVA/MANOVA mostró diferencias espaciales significativas: la abundancia celular más baja se encontró cerca de la desembocadura del río y la más alta en el área más profunda. Prorocentrum lima (Ehrenberg) Dodge, se encontró principalmente sobre las Phaeophyta seguido de las Chlorophyta y Rhodophyta. Gambierdiscus toxicus se encontró principalmente sobre las Phaeophyta seguido de las Rhodophyta y Chlorophyta. Todas las especies halladas en el área del estudio estaban sobre Padina spp. (Phaeophyta). No se encontró ninguna especie de dinoflagelado sobre Acanthophora spicifera (Rhodophyta). Las condiciones ambientales en verano (temperatura, nutrientes, transparencia de agua y la baja velocidad del viento) favorecen el desarrollo de las macroalgas, siendo un substrato adecuado para el desarrollo de dinoflagelados potencialmente nocivos, y posiblemente el vector principal para la extensión de la ciguatera en la costa noroeste cubana.

Palabras clave: dinoflagelados bentónicos, abundancia, Cuba, ciguatera.

\section{REFERENCES}

Adachi, R. \& Y. Fukuyo. 1979. The thecal structure of the marine toxic dinoflagellate Gambierdiscus toxicus gen sp. Nov. Collected in a ciguatera-endemic area. Bull. Jap. Soc. Scient. Fish. 45: 67-71.

Bagnis, R.J., A. Julvez, B. Allaoui, H. Dubray, M.A. Conan, A. Halidi, L. Mieli \& J. Galtier. 1988. Le risque ciguaterique dans l'île de Mayotte (Archipel des Comores). Rev. Internat. Océanog. Medi. 91-92: 43-54.

Barraza, J.E., J.A. Armero-Guardado \& Z.M. Valencia de Toledo. 2004. The red tide event in El Salvador, August 2001-January 2002. Rev. Biol. Trop. 52(Suppl. 1): 1-4.

Bravo-Sierra, E. 2004. Fitoflagelados potencialmente tóxicos y nocivos de costas del Pacífico mexicano. Rev. Biol. Trop. 52(Suppl. 1): 5-16.
Besada, E.G., L.A Loeblich. \& A.R. Loeblich. 1982. Observations on tropical benthic dinoflagellates from ciguatera area: Coolia, Gambierdiscus and Ostreopsis. Bull. Mar. Sci. 32: 723-735.

Bomber, J.W., D.R. Norris \& L.E. Mitchell. 1985. Benthic dinoflagellates associated with ciguatera from the Florida Keys. II. Temporal, spatial and substrate heterogeneity of Prorocentrum lima. p. 45-50. In D.M. Anderson, A.W White \& D.G. Baden (eds.). Toxic dinoflagellates. Elsevier Scientific, Amsterdam, Holland.

Bomber, J. W., M.G.Rubio \& D.R. Norris. 1989. Epiphytism of dinoflagellates associated with the disease ciguatera: substrate specifity and nutrition. Phycology 28: 360-368.

Bordeau, P. \& M. Durand-Clement, 1991. Ichtyosarcotoxine de type ciguatera: Etude écotoxicologique et morphologique de Gambierdiscus toxicus aux Antilles Francaise (Saint Barthélemy). In J.M. Fremy (ed.). Actes Coll. Biotox. Mar. Paris. Publ. CNEMA. p. 61-67.

Carlson, R.D. \& D.R. Tindall. 1985. Distribution and periodicity of toxic dinoflagellates in the Virgin Islands. p. 171-176. In D.M. Anderson, A.W, White \& D.G. Baden. (eds.). Toxic dinoflagellates. Elsevier Scientific, New York.

Carrera, J. \& A. Castro. 2002. Ciguatera, control y prevención en Cuba. Informe técnico del área de Higiene y Epidemiología. MINSAP. Havana, Cuba.

D’Avanzo, C. 1994. Diel oxygen dynamics and anoxic event in an eutrophic estuary of Waquiot Bay. Estuaries 17(1B): 131-139.

Delgado, G., G. Popowski \& R. Nodar. 2000. Primer registro de Prorocentrum lima (Ehr) Dodge 1975, en aguas cubanas. Rev. Invest. Mar. 21(1-3) : 103-105.

Diogéne, G., M. Durand-Clement \& S. Puiseux-Dao. 1992. La ciguatera intoxication alimentaire d'origine marine et la maïtotoxine composante du complexe toxinique ciguatérique. Rev. Scient. Tech. Défense. 2 trim.: $37-47$.

Faust, M.A. 1991. Morphology of ciguatera-causing Prorocentrum lima (Pyrrophyta) from widely differing sites. J. Phycol. 27: 642-648.

Faust, M.A. 1996. Dinoflagellatess in a mangrove ecosystem, Twin Cays, Belize. Nova Hedwigia 112: 447-460.

Fukuyo, Y., 1981. Taxonomical study on benthic dinoflagellates collected in coral reef. Bull. Jap. Soc. Sci. Fish. 47: 967-78. 
Gárate-Lizárraga, I., J.J. Bustillos-Guzmán, K. Erler, M.S. Muñetón-Gómez, B. Luckas \& A. Tripp-Quezada. 2004. Paralytic shellfish toxins in the chocolata clam, Megapitaria squalida (Bivalvia: Veneridae), in Bahía de La Paz, Gulf of California. Rev. Biol. Trop. 52(Suppl. 1): 133-140.

García-Hansen, I., R. Cortés-Altamirano \& A.P. SierraBeltrán. 2004. La marea roja causada por el dinoflagelado Alexandrium tamarense en la costa Pacífica colombiana (2001). Rev. Biol. Trop. 52(Suppl. 1): $59-68$.

Gillespie, N., M. J. Holmes, J. B. Burke \& J. Dolley. 1985. Distribution and periodicity of Gambierdiscus toxicus in Queensland, Australia. p. 183-188. In D.M. Anderson, A.W. White \& D.G. Baden. (eds.). Toxic dinoflagellates, Elsevier, New York.

González, A. 1990. Estudio de la contaminación marina por metales pesados en algunas áreas cubanas. "Tesis presentada en opción al grado Científico de Candidato a Doctor en Ciencias Química". Universidad de la Habana, Cuba. p. 1-120.

Grzebyk, D., B. Berland,, B.A. Thomassin, C. Bosi \& A. Arnoux. 1994. Ecology of ciguateric dinoflagellates in the coral reef complex of Mayotte Island (S.W. Indian Ocean). J. Exp. Mar. Biol. Ecol. 178: 51-66.

Hallegraeff, G.M. 1995. Harmful algal bloom: A global overview. p. 1-22. In G.M. Hallegraeff, D.M. Anderson \& A.D. Cembella. (eds.). Manual on Harmful Marine Microalgae. IOC Manual and Guides, No. 33, UNESCO, Paris.

Heil, C.A., P. Bird \& W.C. Denninson. 1998. Macroalgal habitat preference of ciguatera dinoflagellates at Heron Island, a coral cay in the southeastern great barrier reef, Australia. p. 52-53. In B. Reguera, J. Blanco, M. Fernández \& T. Wyatt. (eds.). Harmful Algae. Xunta de Galicia and International Governmental Commission of UNESCO, Vigo, Spain.

Hernández-Becerril, D.U. \& A. Almazán Becerril. 2004. Especies de dinoflagelados del género Gambierdiscus (Dinophyceae) del Mar Caribe mexicano. Rev. Biol. Trop. 52(Suppl. 1): 77-87.

IOC/UNESCO. 1983. Chemical methods for use in marine environmental monitoring. Manuals and Guides 12 . UNESCO, Paris. 53 p.

IOC/UNESCO. 1993. Nutrient analysis in tropical marine water. Manuals and Guides 33. UNESCO, Paris. 42 p.

La Barbera-Sánchez, A., J.F. Soler, L. Rojas de Astudillo \& I. Chang-Yen. 2004. Paralytic Shellfish Poisoning (PSP) in Margarita Island, Venezuela. Rev. Biol. Trop. 52(Suppl. 1): 89-98.
Littler, M.M \& D.S. Littler 1980. The evolutions of thallus form and survival strategies in benthic marine macroalgae: field and laboratory test of and functional: form model. Amer. Nat.116: 25-44.

McCaffrey, E.J, M.M.K. Shimizu, P.J. Scheuer \& J.T. Miyahara 1992. Seasonal abundance and toxicity of Gambierdicus toxicus Adachi et Fukuyo from O'ahu, Hawaii. p. 145-153. In T.R. Tosteson (ed). Proceedings of the third International Conference on Ciguatera Fish Poisoning. Polyscience, Quebec, Canada.

Montalvo, J.F., M. Cano, J. Díaz, R. Pérez, S.C. Esponda, M.E. César, C.M. Peón \& J. Rendón 2001. Nutrientes en la zona litoral entre los ríos Quibú y Jaimanitas, Ciudad de La Habana, Cuba. Contribución a la Educación y la Protección Ambiental. Cátedra de Medio Ambiente. ISCTN. Vol. 2 (CD) del VII Taller.

Morton, S.L. \& M.A. Faust. 1997. Survey of toxic epiphytic dinoflagellates from the Belizean barrier reef ecosystem. Bull. Mar. Sci. 61: 899-906.

Popowski, G., G. Delgado, M. Sánchez \& R. Nodar. 2001. G. toxicus Adachi y Fukuyo, en el litoral norte de Ciudad de la Habana. Rev. Invest. Mar: 21: 69-72.

Quod, J.P., J. Turquet, G. Diogéne \& V. Fessard. 1995. Screening of extracts of dinoflagellates from coral reefs (Reunion Island, SW Indian Ocean), and their biological activities. p. 815-820. In P. Lassus, G, Arzul, P. Erard, P. Gentien \& C. Marcaillou. (eds.). Harmful Marine Algal Blooms. Lavoisier, Paris.

Saint-Martin, K., M. Durand-Clement \& P. Bourdeau. 1988. Contribution a l'étude des rapports entre les macroalgues et Gambierdiscus toxicus (Dinophyceae), agent causal de la ciguatera. Crypt. Algol. 9(3): 195-202.

Schaffalke, B. 1999. Short-term nutrient pulses as tools to assess responses of coral reef macroalgae to enhanced nutrient availability. Mar. Ecol. Prog. Ser. 182: 305-310.

Sierra-Beltrán, A.P., D.B. Lluch-Cota, S.E. Lluch-Cota, R. Cortés-Altamirano, M.C. Cortés-Lara, M. CastilloChávez, L. Carrillo, L. Pacas, R. Víquez \& I. García-Hansen. 2004. Dinámica espacio-temporal de organismos precursores de marea roja en la costa Pacífica de América del Norte y Centroamérica. Rev. Biol. Trop. 52(Suppl. 1): 99-107.

Taylor, F.J.R. 1985. The distribution of the dinoflagellate Gambierdiscus toxicus in the Eastern Caribbean. In Gabrie, Salvat, B. (eds.). Proc. 5th Int. Coral Reef Symp. Thaiti. Antenne Museum-EPHE, Moorea, French Polynesia, vol.4, p. 423-428.

Taylor, F.J.R \& M.S. Gustavson. 1986. An underwater survey of the organism chiefly responsible for "ciguatera" 
fish poisoning in the Eastern Caribbean Region: the benthic dinoflagellate Gambierdiscus toxicus. p. 95-111. In Proceedings of the 7th. International Diving Science Symposium. Padova, Italy. CMAS, University of Padua, Italy.

Tomas, C.R \& D.G. Baden. 1993. The influence of phosphorus on the growth and cellular toxin content of the benthic dinoflagellate Prorocentrum lima. In T.J Smayda \& Y. Shimizu. (eds.). Toxic phytoplankton blooms in the sea. Elsevier Science, Amsterdam, Holland: p. 565-569.

Tosteson, T.R. 2004. Caribbean ciguatera: a changing paradigm. Rev. Biol. Trop. 52(Suppl. 1): 109-113,

Turquet, J., J.P. Quod, A. Couté \& M.A. Faust. 1998. Assemblage of benthic dinoflagellates and monitoring of harmful species in Reunion Island, SW Indian
Ocean, 1993-1996. p. 44-47. In B. Reguera, J. Blanco, Ma.L. Fernández \& T. Wyatt. (eds.). Harmful algae. Proceedings of the 8th International Conference on Harmful Algae. Xunta de Galicia and Intergovernmental Oceanographic Commission of UNESCO.

Valdés, E., G. Popowski, C. Jiménez. R. Martínez, N. Borrero \& B. Berland. 1992. Ciguatera in Cuba: preliminary results. Bull. Soc. Path. Ex. 85: 522.

Vargas-Montero, M. \& E. Freer. 2004. Presencia de los dinoflagelados Ceratium dens, C. fusus y C. furca (Gonyaulacales: Ceratiaceae) en el Golfo de Nicoya, Costa Rica. Rev. Biol. Trop. 52(Suppl. 1): 115-120.

Yasumoto, T., Y. Oshima, Y. Murakami, I. Nakijama, R. Bagnis \& Y. Fukuyo. 1980. Toxicity of benthic dinoflagellates found in coral reefs. Bull. Jpn. Soc. Sci. Fish. 46: 327-31. 